\title{
Endangered Saudi Arabian plants having ethnobotanical evidence as antidotes for scorpion envenoming
}

\author{
Abdulrahman Khazim Al-Asmari ${ }^{1 *}$, Rajamohamed Abbasmanthiri ${ }^{1}$, Nasreddien Mohammed Abdo Osman ${ }^{1}$ and \\ Byan Abdulrahman Al-Asmari ${ }^{2}$
}

\begin{abstract}
Scorpion sting envenoming in Saudi Arabia posed major public health problems. Conventional treatment with antivenom with its limitations and hazards called for the use of support remediation like prazosin therapy and phytotherapy as alternative solutions in systematic medicine and a trend of use in medicinal plants. The present study is aiming to procure the medicinal plants that exhibit antidotes of scorpion stings which, were scientifically ignored in Saudi Arabia. Current study data of 11 rare and endangered medicinal plants were collected identified up to the family level, in addition to the parts used. The Family Leguminosae was represented by 4 species. The families Acanthaceae, Amaranthaceae, Annonaceae, Euphorbiaceae, Myrtaceae, Plumbaginaceae, and Zygophyllaceae, were represented with a single species each. All of them have got medicinal ability of antidote potential against scorpion venoms. These commonly used herbs that belonged to 8 families were similar in the use of all parts in treatment. This review study may assist the researchers recruiting new natural herbs and their active products as therapeutic agents against scorpion envenoming. However, these medicinal plants are still requiring pharmacological and phytochemical investigations in order to be claimed as effective antidotes in scorpion envenoming syndrome.
\end{abstract}

Keywords: Medicinal plants, Venoms, Scorpion sting, Saudi Arabia, Euphorbiaceae

\section{Introduction}

Scorpions, widely distributed throughout the world [1], have venoms that contain neurotoxins, cardiotoxins, nephrotoxins, hemolytic toxins, nucleotides, amino acids, oligopeptides, phospholipase-A, hyaluroinidase, acetylcholine esterase, histamine, serotonin, 5-hydroxyptamine and proteins that inhibit protease, angiotensinase and succinate dehydrogenase actions [2, 3]. Envenoming degree is controlled by several factors: scorpion species, lethality and dose of venom injected at the time of sting and also on the victim's physiological reactions to venom, demanding a treatment protocol [4]. The common associated

\footnotetext{
* Correspondence: abdulrahman.alasmari@gmail.com

${ }^{1}$ Scientific Research Center, Medical Service Department (MSD), Ministry of Defense, P.O. Box 22454, Riyadh 11495, Kingdom of Saudi Arabia Full list of author information is available at the end of the article
}

symptoms are severe pain and inflammatory reactions, though human death is not very common [1] Cardiac, respiratory, autonomic and metabolic abnormalities are the general clinical features of stung patients that lead to multisystem failure and death $[5,6]$. Most frequent manifestations are pulmonary edema [7], myocardial damage [8], intracerebral haemorrhage [9], brachial plexopathy [10], and renal failure [11] induced by the prolific release of neurotransmitters associated with scorpion envenoming [12]. Drugs like prazosin, angiotensin-converting enzyme (ACE) inhibitors, insulin, scorpion antivenom, with others are some of the current regimens and protocol strategies practiced for patient remediation $[13,14]$.

Herbal sources of medicine were used for more than 5000 years ago and still going on in traditional modern medicine [15]. The diversity of plants in Saudi Arabia is 
due to its unique habitats that stretch along large spatial area. A total of 2250 species (including pteridophytes and gymnosperms) in 142 families are represented in the flora of the Kingdom of Saudi Arabia. Of these, there are 242 endemic and 600 rare and endangered species in the wild [16]. The number of threatened species is increasing annually as a result of adverse environmental conditions and anthropogenic activities [17]. Medicinal plants of Saudi Arabian were employed in treatment of human and animal diseases. Reports of plant families like: Leguminosae, Acanthaceae, Amaranthaceae, Annonaceae, Araceae, Myrtaceae, Plumbaginaceae and Euphobiaceae as medically important lead to the continuous work process on other plants also [18-20]. More than a quarter of drugs are of plant origin, whereas 121 active compounds and synthetically produced analogues come from natural precursors, a situation that cannot under estimate the importance of phytomedicine [20].

Two thirds of the Arabian Peninsula is occupied by the Kingdom of Saudi Arabia, covering a wide range of natural sites with great biodiversity and synergistic framework of associated ecosystems [21]. The activity of many plants against scorpion envenoming has been reported previously. However, according to the literature review and to the best of our knowledge, a number of rare and endangered plants found in Saudi Arabia, only few of them have been reported for their anti-scorpion activity.

In this study the aim is to follow a survey of rare and endangered medicinal plants in the kingdom and attempt to reflect some of their uses in treatment of scorpion stings and some other diseases.

\section{Methods}

Information concerning medicinal plants of Saudi Arabia was collected from all available sources. In addition to the facilities provided by Scientific Research Center,
Medical Services Department (MSD), Ministry of Defense, Riyadh, Saudi Arabia, that included library and access to electronic data, general use of internet websites and specific search engines such as Science Direct, Google, PubMed and other biological and chemical abstract libraries were also used. Literature search keywords of this article were "Saudi Arabian medicinal plants, rare and endemic and endangered plants of Saudi Arabia, ethnobotanical evidences in scorpion sting and natural products". Selection of plants was focused on their therapeutic potentials as antivenom in folklore remedies. Specific searches were also made to enlist already reported antivenom constituents with possible mechanism to support the antivenom characteristics of medicinal plants of Saudi Arabia. The outcome was again checked and compared with the literature of current drugs that are employed in combating signs and symptoms of scorpion envenoming.

\section{Results \\ Medicinal plants used against scorpion envenoming Plant parts used}

In this study, a total of 11 endangered species belonging to 8 families were reported for their medical application including scorpion sting in Saudi Arabia. Table 1, presented the number of the plant species in each family, and stating those endangered ones. It showed 11 rare and endangered medicinal plants and the specific parts that had potential benefit for treating scorpion stings. The Family Leguminosae was represented by 4 species. The families Acanthaceae, Amaranthaceae, Annonaceae, Euphorbiaceae, Myrtaceae, Plumbaginaceae, and Zygophyllaceae, were represented with a single species each. All these presented species have got medicinal ability antagonising scorpion venoms. The plant species reported in this study are widely known to be used to treat scorpion stings in Saudi Arabia. Table 2 summarizes the plant parts used for this purpose, in addition to their

Table 1 Status of Saudi Arabian plants used for treatment of scorpion stings

\begin{tabular}{|c|c|c|}
\hline Family & Species & Status \\
\hline Acanthaceae & Blepharis maderaspatensis (L.) Roth & Endangered \\
\hline Amaranthaceae & Amaranthus spinosus L., Sp. (1753) & Endangered \\
\hline Annonaceae & Annona squamosa & Occasional, Endangered non-Endemic \\
\hline Euphorbiaceae & Croton lobatus & Endangered \\
\hline Leguminosae (Fabaceae or Papilionaceae) & $\begin{array}{l}\text { Abrus precatorius } \\
\text { Clitoria ternatea } \\
\text { Desmodium gangeticum } \\
\text { Glycyrrhiza glabra }\end{array}$ & $\begin{array}{l}\text { Locally common, Endangered non-Endemic } \\
\text { Endangered } \\
\text { Extinct non Endemic } \\
\text { Endangered non Endemic, Rare }\end{array}$ \\
\hline Myrtaceae & Myrtus communis & Endangered non Endemic, Rare \\
\hline Plumbaginaceae & Plumbago zeylanica & Endangered \\
\hline Zygophyllaceae & Balanites aegyptiaca & Endangered \\
\hline
\end{tabular}


Table 2 Botanical information of 11 endangered medicinal plants in Kingdom of Saudi Arabia

\begin{tabular}{|c|c|c|c|c|}
\hline Family & Species & Local Name & Parts Used & References \\
\hline Acanthaceae & Blepharis maderaspatensis (L.) Roth & Atrara & Leaves & {$[22]$} \\
\hline Amaranthaceae & Amaranthus spinosus L., Sp. (1753) & Spiny amarantus & Leaves, Stem, Root & {$[23]$} \\
\hline Annonaceae & Annona squamosa & (Qishda, Safarjal Hindi) & Leaves, Root & {$[24,25]$} \\
\hline Euphorbiaceae & Croton lobatus & Thufailan & Leaf & {$[26]$} \\
\hline $\begin{array}{l}\text { Leguminosae } \\
\text { (Fabaceae or Papilionaceae) }\end{array}$ & $\begin{array}{l}\text { Abrus precatorius } \\
\text { Clitoria ternatea } \\
\text { Desmodium gangeticum } \\
\text { Glycyrrhiza glabra }\end{array}$ & $\begin{array}{l}\text { Joha } \\
\text { Gatad Marioti } \\
\text { Hiraija Mabthora } \\
\text { Abushoak plant }\end{array}$ & $\begin{array}{l}\text { Root } \\
\text { Leaf, Root, Stem } \\
\text { Root } \\
\text { Root }\end{array}$ & $\begin{array}{l}{[27]} \\
{[28,29]} \\
{[30]} \\
{[30]}\end{array}$ \\
\hline Myrtaceae & Myrtus communis & (Tha'ab) Ithba - Dharf & Leaves & {$[31]$} \\
\hline Plumbaginaceae & Plumbago zeylanica & Alhilo (Sweet) plant & Whole plant, Root & {$[32]$} \\
\hline Zygophyllaceae & Balanites aegyptiaca & Farfakh - Namose & Leaves, Stem & {$[27]$} \\
\hline
\end{tabular}

scientific and local names. The morphological detailed information of each species were mentioned accordingly:

\section{The family Acanthaceae}

\section{Blepharis maderaspatensis (L.) Roth}

Blepharis maderaspatensis is a $2.5 \mathrm{~m}$ (stem height) scrambling perennial herbal plant that belongs to the family Acanthaceae. It has four hairy leaves that are elliptic and entire, at each node, with axillary spike inflorescence. The flowers are found in the clustered form or solitary. The veins and venules are pale-blue, purple or creamy-white. The margins and clinging bristles retrorse-barbed with bracts that are $5-10 \mathrm{~mm}$ long. The capsule and the corolla are $0.5-0.8$ and $0.8-1.3 \mathrm{~cm}$ long (respectively). They are ovoid in shape, shining, glabrous and brownish in colour. Mostly spreading in the savannah zone, Tropical Africa [33], Yemen, Saudi Arabia, Iran to India (Fig. 1) [34, 35].

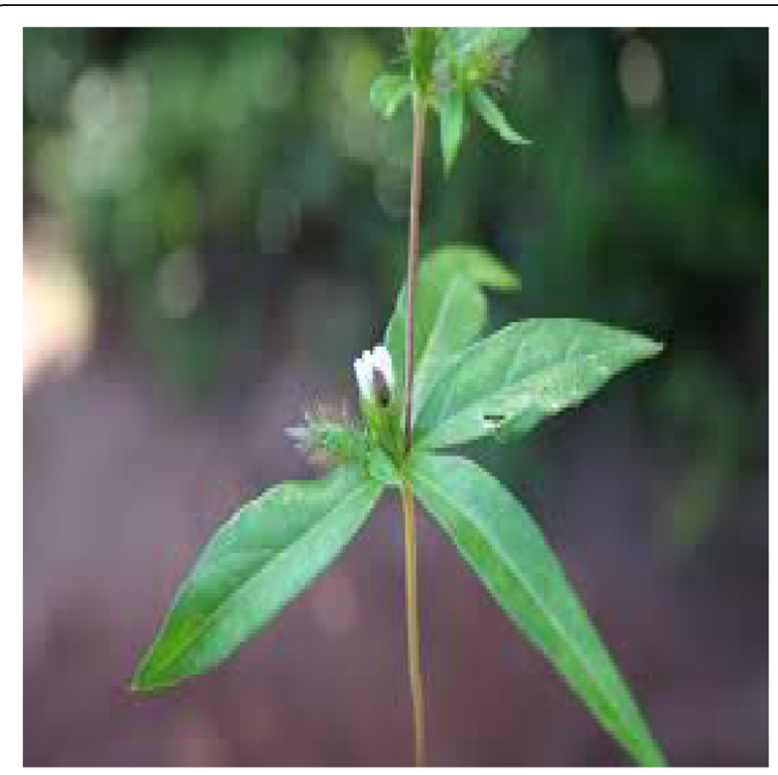

Fig. 1 Blepharis maderaspatensis. This endangered species belongs to the plant family Acanthaceae (Copy source Jacob Thomas Pandalayil)

\section{Medicinal use}

This herbal plant is usually used to treat the general nervous disorders, scorpion stings, skin boils, headaches, general wounds and cuts, and bone fractures [36-40]. Effectivity of this plant (B. maderaspatensis) in treatment comes from its potential ability as a natural scavenger source of free radicals due to its contents of alkaloids, terpenoids, steroids, coumarins, flavonoids and glycosides [40].

\section{The family Amaranthaceae}

Amaranthus spinosus L., Sp. (1753)

Amaranthus spinosus is a $75 \mathrm{~cm}$ tall annual and erect herb, with either stout or weak axillary spines, which are paired. It is glabrous with branches and the apex is obtuse to subacute with leaves that are rhomboid to ovate. There are green spikes which, are axillary and terminal, rather dense and few, in general infloresence, whilst all male flowers are found at the upper parts of spikes and all the female flowers are found at the lower parts of spikes. The perianth is longer than the bracts. With wrinkled capsule, segments of the perianth are 3-5 and 2-3 flexuous stigmas, whilst, the simple leaves exstipulate or almost entire, in opposite or alternate position. It also has a raceme inflorescence, sometimes, with a loose spike or dense head, bracteates, panicle or cyme. The hyaline bracts are sometimes coloured or white, with single flowers or more. It has unisexual or bisexual flowers that are regular. These flowers sometimes arranged in cymules; whilst some of the lateral ones are in the form of scales, hooks or spines. The perianth is uniseriate and membranous. The tepels are free or somewhat united at the base, they are variously coloured and often green to white. Petals and stamens are numerous and positioned in opposite sites. The superior pendulous to erect ovary is unilocular, with one to numerous ovules. There is capitate stigma that is filiform to long with long to short style and a basal placentation. The irregularly rupturing fruit has a capsule that is indehiscent or circumcissile with ovoid or round seeds 
(Fig. 2) [35]. This pantropical herbal plant (Amaranthus spinosus) is only found in scattered places in the southwest region as an endangered species [41, 42].

\section{Medicinal use}

It is used as a medicinal herb to treat stomach aches, constipation, oliguria, pyrexia, jaundice (boiled leaves and roots) and gonorrhoea (root extract) [43, 44]. The root paste is applied on snakebite or scorpion sting (Doctrine of Signatures) [45].

\section{Family Annonaceae}

The family Annonaceae has about 122 genera and 1200 species, usually seen in the evergreen tropical forests and lowland of America, Asia to Australia whilst, only one genus is extant in Saudi Arabia (Annona).

\section{Annona squamosa}

This species represents shrubs and trees, whose wood and leaves have got aromatic compounds. The terminal flowers are yellowish, but usually green. When woods are older, the axillary opposed leaves are borne in panicles or fascicles but, usually leaves are exstipulate, entire with alternate position. Fruits are rarely enlarged whilst, the petals are imbricate and rarely three to four but, mostly in two series of six. The deciduous or persistent, valvate or imbricate sepals are distinct two, in number, variously united but, rarely three. There are numerous hypogynous stamens, found in several series that are spirally imbricate. The longitudinally slit opening of the anther loculi are adnate to the connective, whilst, there

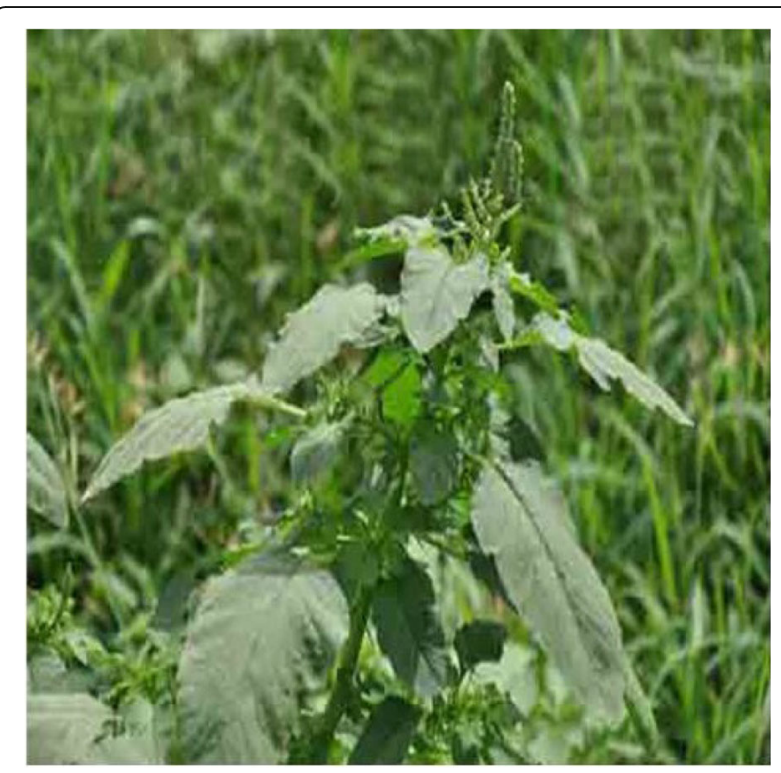

Fig. 2 Amaranthus spinosus. This endangered species belongs to the plant family Amaranthaceae (Copy source Jacob Thomas Pandalayil) are thick and very short filaments. Placentas are found parietal in the ovary which is usually free or rarely found united in one locule. The style is rarely connate but, usually free, short and thick and the carpels are rarely found solitary but, they are either few or numerous. The stigma which has one or two ovules sometimes bilobed or sulcate but, usually oblong or capitate. The seeds are either arillate or not. The fruit full carpels are rarely joined together in a mass of several locules but, usually free and stipitate (Fig. 3) [34, 35].

\section{Medicinal use}

The paste of leaves is used to kill lice, and the whole leaves were used to treat scorpion stings [46]. Employing various solvents, phytochemical screening tests done to extract and collect the different biological chemical components that included phenolic compounds, saponins, alkaloids, flavonid terpeniods, glycosides and steroids. The extraction method implied on the used parts of the plant and the type of used solvents, control the presentation of these biological and chemical compounds [47].

\section{Family Euphorbiaceae Croton lobatus}

The species Croton lobatus (Fig. 4) [34], which is a tropical wild plant is commonly used in African traditional medicine to prepare remedies for many diseases (malaria, pregnancy troubles, dysentery) [48]. Numerous studies have dealt with the constituents of Croton and these studies have revealed that the presence of sesquiterpenes $[49,50]$, diterpenes [51, 52], triterpenes [53] steroids, flavonoids

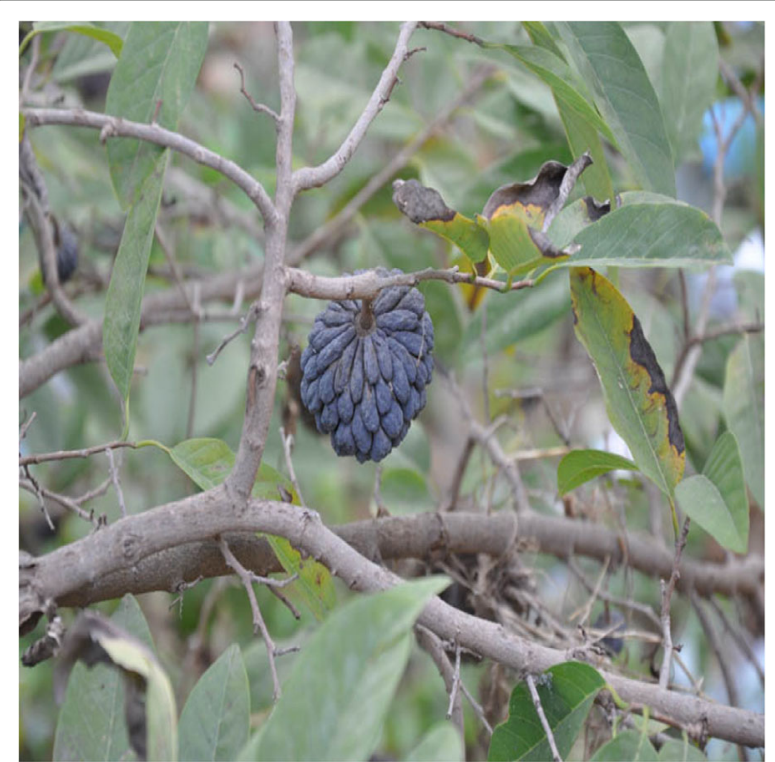

Fig. 3 Annona squamosa. This occasionally, endangered, nonendemic species belongs to the plant family Annonaceae (Copy source Jacob Thomas Pandalayil) 


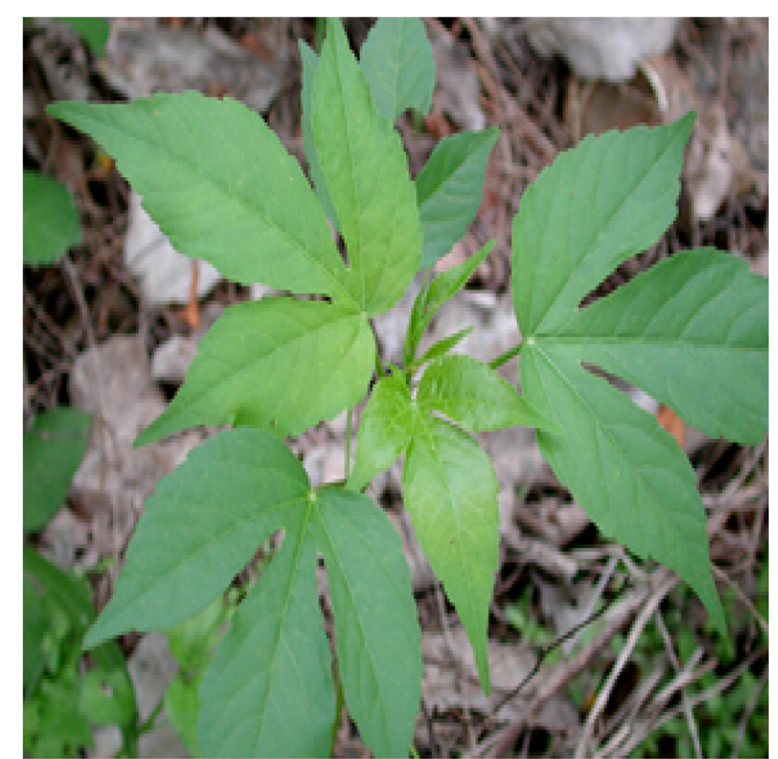

Fig. 4 Croton lobatus. This endangered species belongs to the plant family Euphorbiaceae (Copy source Jacob Thomas Pandalayil)

[54] and alkaloids [55]. From the leaves and the stem bark of C. lobatus, several compounds were isolated among which are the nitrogen compounds, polyphenol, sterols, triterpenes and diterpenes [56, 57].

\section{Medicinal use}

A whole plant infusion is used as a topical bath to treat skin diseases. In Nigeria the leaf sap is applied to lessen the pain of scorpion stings.

\section{The family Leguminosae (Fabaceae or Papilionaceae) Abrus precatorius}

The species Abrus precatorius that belongs to the family Fabaceae has common names (rosary pea and ratti) and is used as a medicinal herb to treat various diseases though, it is considered an endangered plant in Saudi Arabia (Fig. 5) [35]. The different parts of the plant are used as anti-ophthalmic, anti-phlogistic, tonic, emetic, aphrodisiac and purgative [58]. Though the seeds of Abrus precatorius contain deadly poisonous compounds but, storage of these seeds upon long refrigeration was reported to convert the toxic form of abrin to the mitogenic form $[59,60]$.

\section{Medicinal use}

Root powder is taken orally along with cow's milk to treat scorpion sting [61].

\section{Clitoria ternatea}

The species Clitoria ternatea is a perennial twining herb. There are imperipinnate leaves with 2.5 to $2 \mathrm{~cm}$ long petioles, in addition to acute and linear, four mm long stipules. There are five to seven caute or obtuse, elliptic-oblong

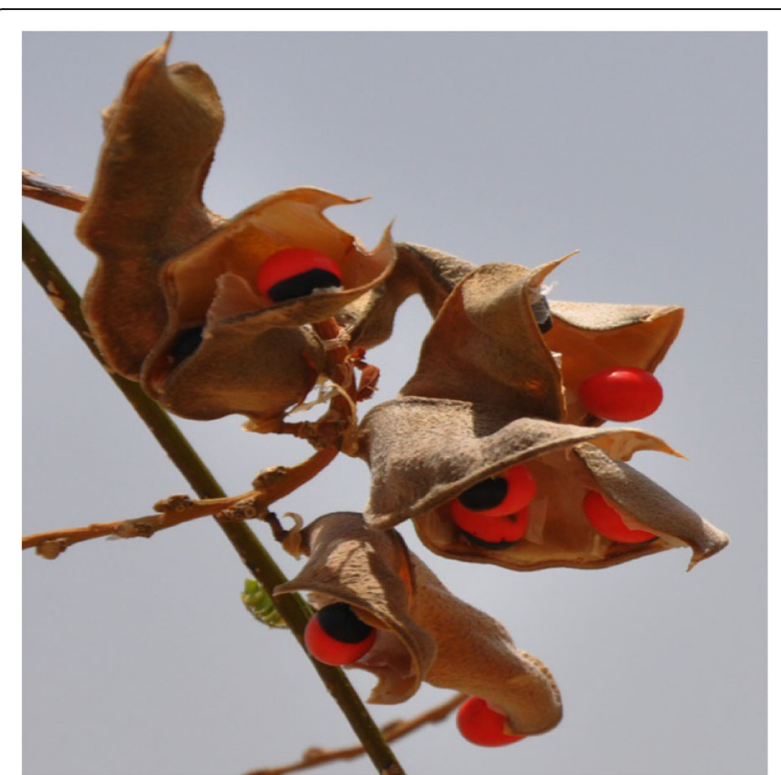

Fig. 5 Abrus precatorius. This locally common, endangered, nonendemic species belongs to the plant family Leguminosae (Fabaceae or Papilionaceae) (Copy source Jacob Thomas Pandalayil)

leaflets which, are subcoriaceous of 2.5 to 5 by 2 to $3.2 \mathrm{~cm}$ dimensions that have filiform stipules (Fig. 6) [34]. The terete stems are mostly pubscent. There are axillary solitary flowers that sometimes have white or blue coloration but, usually standard bright with an orange centre. The smooth yellowish brown seeds are numbered six to ten.

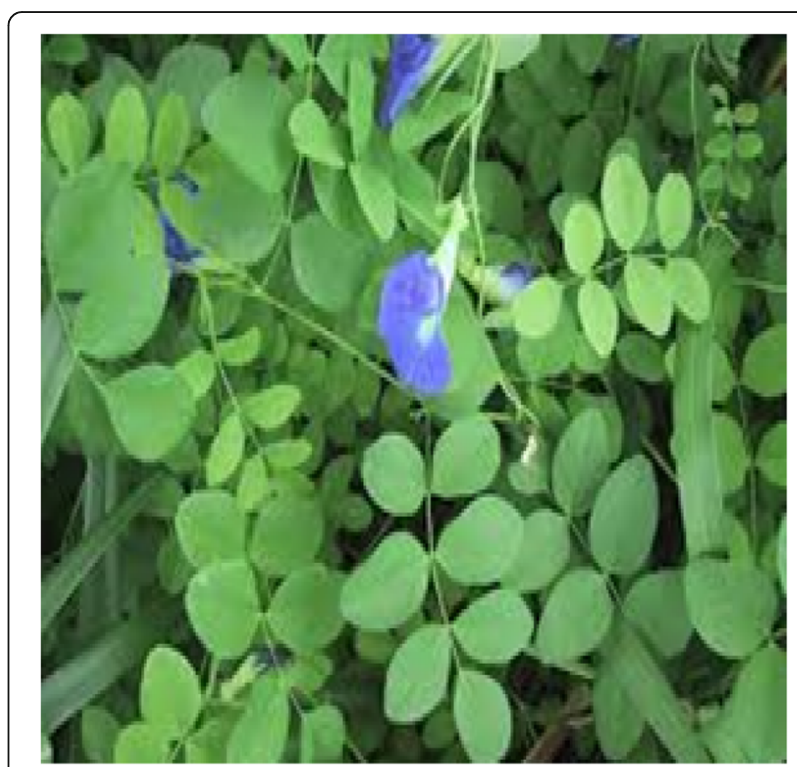

Fig. 6 Clitoria ternatea. This endangered species belongs to the plant family Leguminosae (Fabaceae or Papilionaceae) (Copy source Jacob Thomas Pandalayil) 


\section{Medicinal use}

The parts of this plant used in treatment are the leaves and roots that usually deals with animal stings especially, scorpion stings and snakebites (flowers, stems and roots,) in India [62]. It is also used as an anthelmintic, in urogenital disorders, infections and general body aches [63]. Moreover, this plant has various pharmacological characteristics in functioning as vascular smooth muscle relaxant, insecticidal, blood platelet aggregation inhibitor, antidiabetic, local anaesthetic, diuretic, anti-inflammatory, antimicrobial, antipyretic and analgesic [64].

\section{Desmodium gangeticum}

This one $\mathrm{m}$ tall stout herbal species with prominently deep growing and spreading lateral roots has a system of either five to fifteen or more tap roots that are poorly developed. These long and very strong lateral roots are in the form of cords that are smooth and uniformly cylindrical. The strand of wood is thick in the center surrounded by a tough bark which, might be thin but, color is light yellow. The outer surface of the root has a yellowish brown color and it deeply grows from two to three feet (Fig. 7) [34].

\section{Medicinal use}

This herbal plant has medicinal uses in India (ayurveda) $[65,66]$ for treatment of scorpion sting, snakebites, diabetes mellitus and ulcer $[67,68]$. The aerial parts of the herb extracts are identified as N,N-dimethyltryptamine, sterols and other derivatives, whilst, the root components are desmodin, gangetinin, gangetin and three more pterocarpinoids [69].

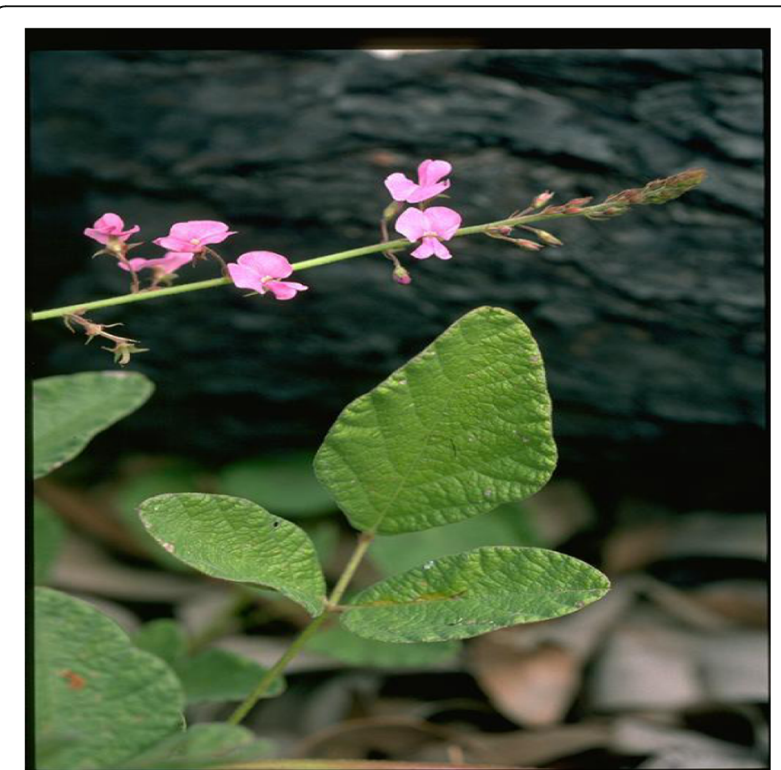

Fig. 7 Desmodium gangeticum. This extinct non-endemic species belongs to the plant family Leguminosae (Fabaceae or Papilionaceae) (Copy source Jacob Thomas Pandalayil)

\section{Glycyrrhiza glabra}

This species name (in Greek) is sweet root and it is a two $\mathrm{cm}$ tall evergreen shrub. Its leaves are bright green and oppositely positioned with either elliptic or ovate shape and by crushing they diffuse an aromatic odor. The axillary cyme flowers are either few or solitary and having white colour. When the flowers are fully open the petals and sepals will be reflexed (Fig. 8) [70]. It is famous for its use in confectionery, as a flavor for liquorice. The glycyrrhizin component of its rhizomes is sweeter than sugar by fifty times. Locally made liquorice confectionery is prepared by using several species that belong to the genus Glycyrrhiza.

\section{Medicinal use}

Its involvement in herbal medicine is represented in masking some medicinal preparations unpleasant tastes, scorpion stings, throat lozenges, cough mixtures, indigestion, inflammatory stomach conditions, stomach ulcers, and mouth ulcers [71].

\section{The family Myrtaceae \\ Myrtus communis (the common Myrtle)}

There are 22 genera belonging to this plant with at least 440 species. In Saudi Arabia there are seven species that belong to three genera and all species have worldwide distribution with often existence within saline habitats. Because of the beautiful and attractive berries, foliage and flowers, it is being widely grown. This perennials shrub has exstipulate, pinnatifid, undivided, basal and alternate leaves. Its inflorescence is either compound or

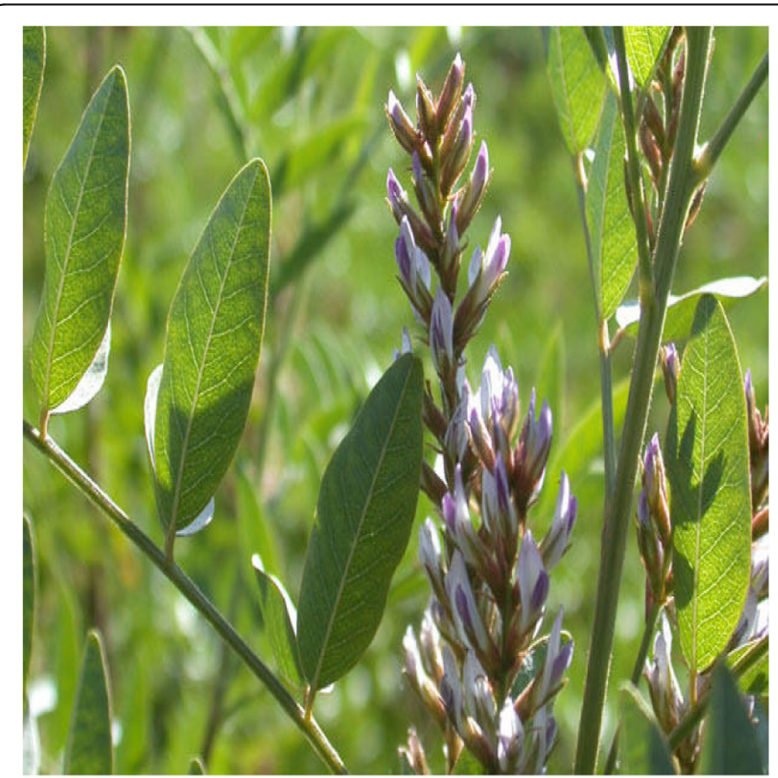

Fig. 8 Glycyrrhiza glabra. This endangered non endemic, rare species belongs to the plant family Leguminosae (Fabaceae or Papilionaceae) (Copy source Jacob Thomas Pandalayil) 
simple, either cymose or racemose and bracteate. It has hypogynous, complete, five merous flowers. It has a showy, coloured, scarious, plicate, strong, papery, lobed or dentate, infundibular or tubular, gamosepalous Calyx. There is either polypetalous or gamopetalous corolla with stamens on their tube on opposed positions with lobes. There is a single ovule in the single ovary and the pistil has five styles and five capillaries. There are circumscissile, either irregularly dehiscing or indehiscent, achene-like fruits that are often enclosed in calyx or being membranous, with a straight embryo (Fig. 9) [35].

\section{Medicinal use}

Since the old days of Greece era and the Unani System of Medicine this herb was used as one of the important drugs. The leaves, berries and extracted oils were employed in flavouring of foods and wine beverages, in addition to treatment of several ailments like leucorrhoea, deep sinusitis, haemorrhages, rheumatism, vomiting, dysentery, diarrhoea, and gastric ulcer. It is also used in treatment of scorpion stings, in addition to hair fall in cosmetology [6]. In past times, ripe fruits were used as food integrators because of their high vitamin contents and they also embody lots of other biologically active components such as antioxidants, malic acid, citric acid, sugars, fibres, fixed oil, essential oil, coumarins, flavonoids and tannins [6].

\section{Family Plumbaginaceae \\ Plumbago zeylanica}

This species is commonly named the Ceylon leadwort, wild leadwort or doctorbush. It is one of a group of 240

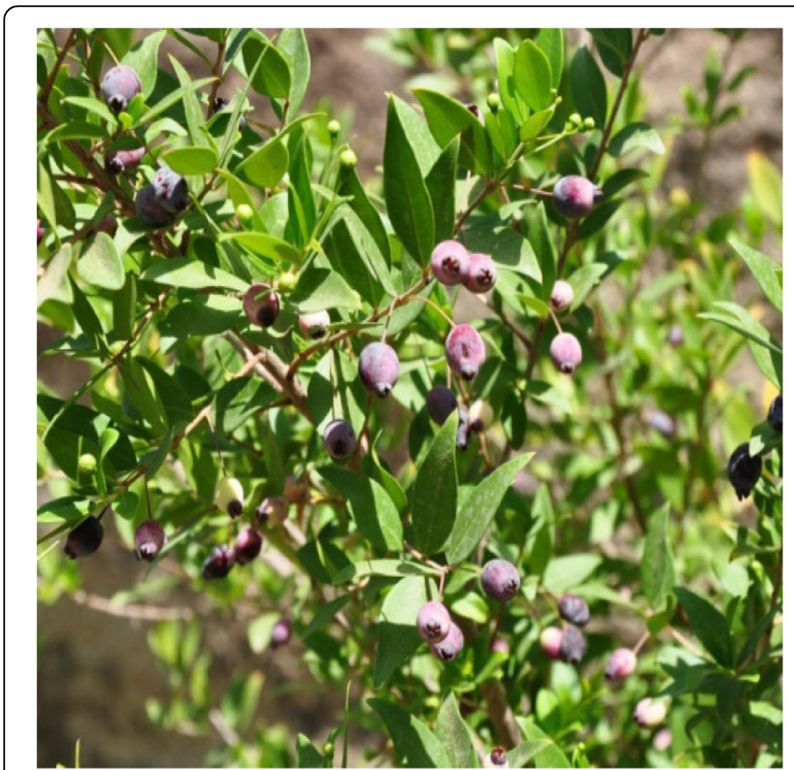

Fig. 9 Myrtus communis. This endangered non endemic, rare species belongs to the plant family Myrtaceae (Copy source Jacob Thomas Pandalayil) species belonging to 25 genera that have worldwide distribution in the tropics and subtropics of which, 32 species belonging to six genera are found in Saudi Arabia. This species also is popularly known throughout India and Asia for treating intestinal worms, infections and skin diseases. This plant can be considered as an undershrub, a perennial herb or with a complete annual cycle. It has leaves with either spiny or coriaceous, persistent stipules, often fleshy, either subsessile or petiolate, with either alternate opposite position, either compound or simple. This plant has an inflorescence with solitary flowers and cymes are either compound or simple, whilst, there is an absent or a rarely annular, depressed or convex disc; hypogynous, ebracteate, five to four-merous, rarely zygomorphic, actinomorphic, hermaphrodite flowers. In bud the sepals are imbricate, rarely connate basally or free and they are usually five in number but, rarely four. There are rarely valvate petals, contorted or imbricate, clawed, basally connate or free, either absent or rarely three but usually four to five. The anthers are dehiscent longitudinally in the form of two cells, whilst, the stamens are in the form of one to three whorls of five that usually count five to a total of fifteen. There is axile placentation of carpels that count five or four, the superior syncarpous ovary is five to three-locular, whilst, the either two or more ovules are also either obscurely lobed or capitate with simple stigma,and simple, terminal style. The fruit capsule is either septicidal or loculicidal, and it is rarely a berry but, could either be a stony drupe or schizocarpic. The either nonendospermic or endospermic seeds are contained in a capsule of one to several ones (Fig. 10) [35].

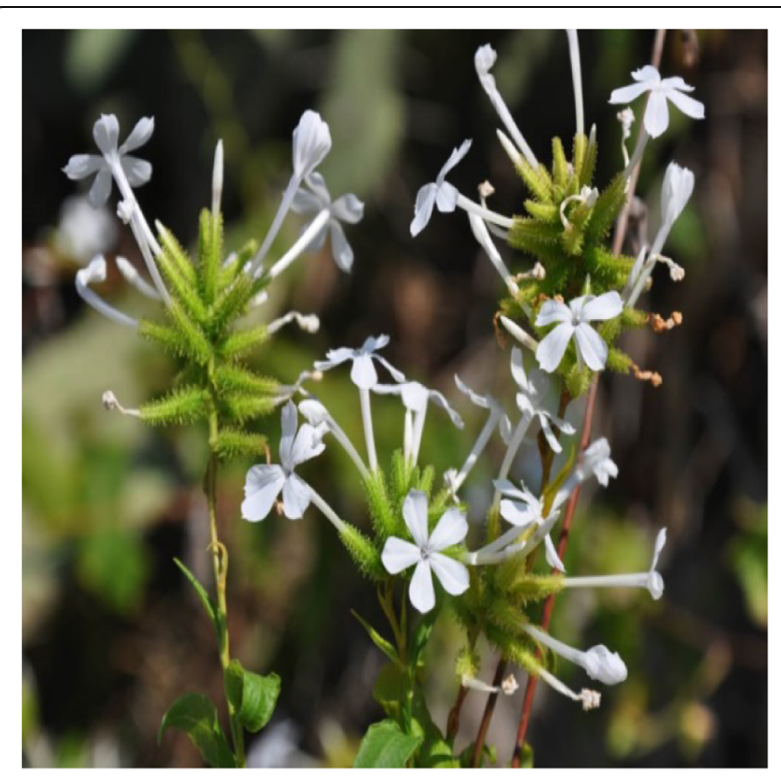

Fig. 10 Plumbago zeylanica. This endangered species belongs to the plant family Plumbaginaceae (Copy source Jacob Thomas Pandalayil) 


\section{Medicinal use}

The major part that had been intensively (due to the extensive pharmacological uses) used was the root and one of its extracts was employed in treatment of scorpion sting sites to relieve pain, topically [72]. This plant has been found to be effective in treatment of several clinically ill patients of hookworm, hemorrhoids, ulcers, dermatitis, ringworm, scabies, leprosy and other multiple inflammations [73]. Wound healing, swellings, rheumatic pain, tuberculosis, syphilis and gonorrhoea, were treated by the leaves, roots and bark powder, whilst, the pulped roots and the aerial parts were used as an abortifacient [74]. Breath shortness is treated by oral root infusion, whilst, chest, throat and mouth inflammations are treated by swallowing the mixture of boiled milk and a decoction of the root [75].

\section{Family Zygophyllaceae Balanites aegyptiaca}

This tree belongs to the tropical zones where it is named the 'desert date' (Fig. 11) [35]. It grows up to ten meters in height with spines, and is usually found in the dry lands of South Asia and Africa, having wide distribution [76].

\section{Medicinal use}

It has been used in traditional medicine to treat several illnesses such as fever, asthma, stomach aches, hemorrhoids, diarrhea, constipation, dysentery, epilepsy, syphilis, malaria, wounds, infection, intestinal worm and jaundice. Scorpion stings were treated by the pulp of the fruit, whilst, as a vermifuge the bark of the stem was

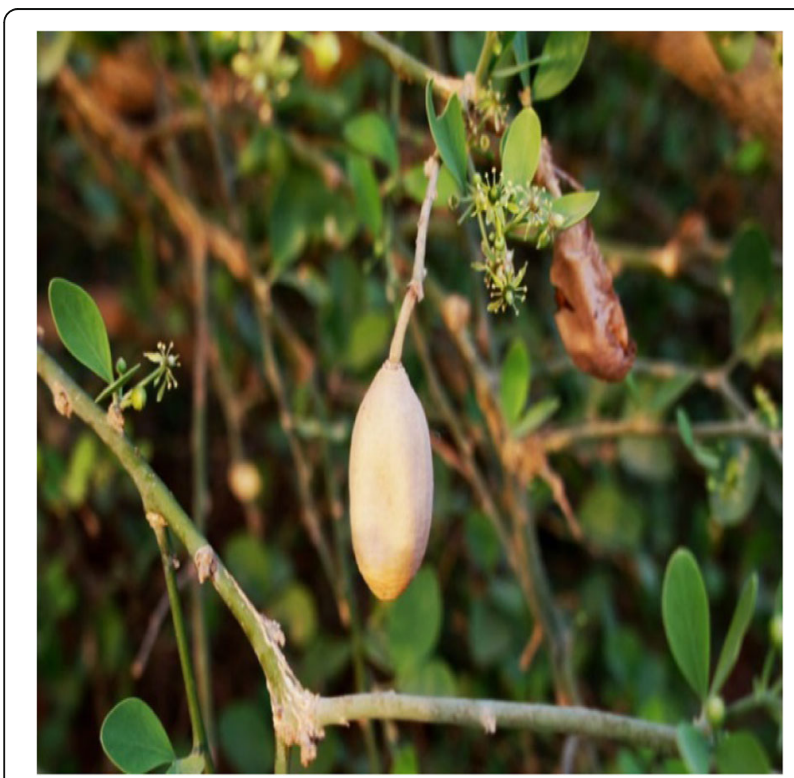

Fig. 11 Balanites aegyptiaca. This endangered species belongs to the plant family Zygophyllaceae (Copy source Jacob Thomas Pandalayil) used [77]. The fruits of this tree were reported to have organic acids, flavonoids, saponins, alkaloids, carbohydrates, lipids and proteins. In addition, products of this tree, through experiment, proved to have antinociceptive properties, antioxidant activity, cardioprotective, antivenin, analgesic, anti-inflammatory, mosquito larvicidal, hepatoprotective, antidiabetic, antiviral, wound-healing, hypocholesterolemic, diuretic, anticancer, antimicrobial and antioxidant activities [76]. Figure 12 was created to show a summary of the presented results in a flow chart form.

\section{Discussion}

Recent surveys reported that the flora of the Middle East is very rich and embodies more than 2600 species of plants. Studies on more than 700 of them confirmed medicinal and pesticidal use [78-81]. In the Arab traditional medicine about 250 species are employed in treating several diseases, till now [78, 82-84].

In this study, the families Acanthaceae, Amaranthaceae, Annonaceae, Euphorbiaceae, Myrtaceae, Plumbaginaceae, and Zygophyllaceae, were represented with a single species each. Each representative species of these families has medicinal uses that have one common characteristic in being used as antidotes for scorpion stings. These plant species also have other medicinal uses and they are endangered with extinction, at least in Saudi Arabia.

The species Blepharis maderaspatensis, that belongs to the family Acanthaceae, is a herbal plant known locally as 'Atrara' and its leaves [22] are usually used to treat scorpion stings. Other remedial uses include general nervous disorders, skin boils, headaches, general wounds and cuts, and bone fractures [36-40]. Effectivity of this plant in treatment comes from its potential ability as a natural scavenger source of free radicals due to its contents of alkaloids, terpenoids, steroids, coumarins, flavonoids and glycosides [40].

The plant family Amaranthaceae is represented by one endangered species Amaranthus spinosus which, is known locally as 'Spiny amarantus'. The boiled leaves and roots of this medicinal herb plant [23] are used to treat stomach aches, constipation, oliguria, pyrexia and jaundice. Whilst, the root extract is used in treating gonorrhoea $[43,44]$. The root paste is applied on snakebite or scorpion stings (Doctrine of Signatures) [45].

The plant family Annonaceae is represented by one occasionally, endangered, non-endemic species Annona squamosa. It is known locally as 'Qishda and Safarjal Hindi', and the paste of leaves was usually used to kill lice but, the whole leaves [24, 25] are used to treat scorpion stung victims [46]. Previous phytochemical screening tests were done by employing various solvents, in extracting and collecting the different biological chemical components. The isolated products included phenolic compounds, saponins, alkaloids, flavonid terpeniods, 


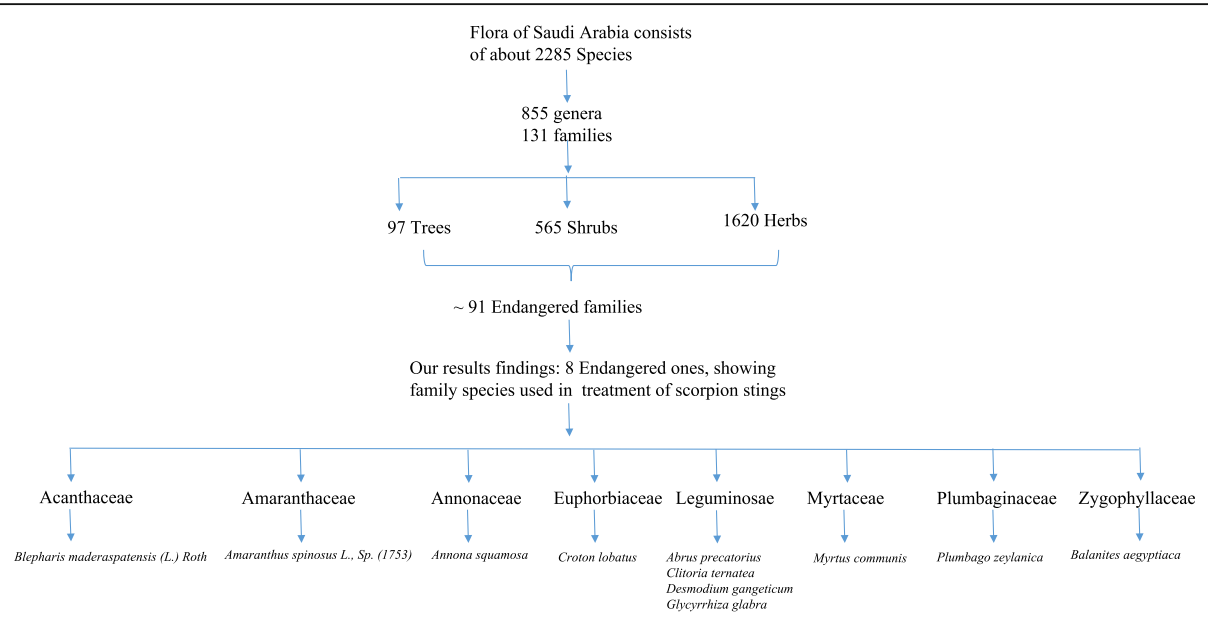

Fig. 12 Flow-chart showing endangered plant species used in treatment of scorpion sting

glycosides, and steroids [47]. Generally, all plant species presented in this study, are somehow endangered by vanishing and being extinct in Saudi Arabia and the Middle East, altogether. Environmental and detrimental climatic changes, overharvesting of wild species and destruction of their natural habitats are threatening processes that handicap the availability of medicinal plant resources [85-87]. Unless serious precautionary steps are taken, within the next 10 years, about one third of native plants, including several species that are found in the desert or semiarid and dry regions, will vanish, forever.

The plant family Euphorbiaceae is represented by a single species, Croton lobatus which, is known locally as 'Thufailan' and it is also endangered by extinction. Infusion of the whole plant is used as a topical bath to treat skin diseases whilst, the leaf sap is applied to lessen scorpion sting pains [26]. Herbal medicinal resources are becoming increasingly interesting, worldwide. With the convincing ability of treating several and various diseases, laboratory investigations in the fields of pharmacology and bioactive ingredients properties reflect a crucial demand to take protective measures [85-87].

Myrtus communis is known locally as 'Tha'ab, Ithba and Dharf' and belongs to the plant family Myrtaceae. This rare, non-endemic endangered herbal plant species had been used as one of the important drugs, since the old days of Greece era and the Unani System of Medicine. The leaves, berries and extracted oils were employed in flavouring of foods and wine beverages [31]. It is also used to treat several ailments like leucorrhoea, deep sinusitis, haemorrhages, rheumatism, vomiting, dysentery, diarrhoea, and gastric ulcer [31]. It is also used in treatment of scorpion stings, in addition to hair fall in cosmetology [6]. In past times, ripe fruits were used as food integrators because of their high vitamin contents and they also embody lots of other biologically active components such as antioxidants, malic acid, citric acid, sugars, fibers, fixed oils, essential oils, coumarins, flavonoids and tannins [6]. In regions of the Middle East, there are more than 2600 plant species that include at least 700 species that are useful as medicinal herbs or as botanical pesticides. In the Arabian countries like Egypt, Yemen, Morocco, Syria and others, recognized researches have been and still being done in these fields of herbal plants and traditional medicine [88-91], though, some species are becoming rare and endangered by extinction, like these ones we have selected from Saudi Arabia. In spite of these abundant numbers of herbal plants in the Arabian countries fauna, rarely were they tested to treat such envenoming cases of scorpion stings or snake bites.

The plant family Plumbaginaceae is represented by The endangered species Plumbago zeylanica whose, local name is Alhilo (the sweet plant). Its roots were the parts that were mostly employed in pharmacological uses intensively [32], whilst, its extracts were employed topically, in treatment of scorpion stung sites to relieve pain [72]. This plant has been found to be effective in treatment of several clinically ill patients of hookworm, hemorrhoids, ulcers, dermatitis, ringworm, scabies, leprosy and other multiple inflammations [73]. This herbal plant has been used in a multitude of serious diseases like wound healing, swellings, rheumatic pain, tuberculosis, syphilis and gonorrhoea, employing leaves, roots and bark powder. Whilst, the pulped roots and the aerial parts were used as an abortifacient [74]. Breath shortness is treated by oral root infusion, whilst, chest, throat and mouth inflammations are treated by swallowing the mixture of boiled milk and a decoction of roots [75].

The plant family Zygophyllaceae is represented by the herbal tree species Balanites aegyptiaca which, is also an 
endangered species, known locally by the names Farfakh and Namose [27]. Several illnesses such as fever, asthma, stomach aches, hemorrhoids, diarrhea, constipation, dysentery, epilepsy, syphilis, malaria, wounds, infection, intestinal worm and jaundice. Scorpion stings were treated by the pulp of the fruit, whilst, as a vermifuge [77]. The fruits of this tree were reported to have organic acids, flavonoids, saponins, alkaloids, carbohydrates, lipids and proteins. In addition, products of this tree, through experiment, proved to have antinociceptive properties, cardio protective, antivenin, analgesic, antiinflammatory, mosquito larvicidal, hepatoprotective, antidiabetic, antiviral, wound-healing, hypocholesterolemic, diuretic, anticancer, antimicrobial and antioxidant activities [76]. Some plant species from North African Mediterranean region coasts were thoroughly investigated in Egypt recently. Only eight families that have just 230 species were investigated and recorded [91].

In this recent study, the plant family Leguminosae (Fabaceae or Papilionaceae) is represented by four different genera and species, Abrus precatorius, Clitoria ternatea, Desmodium gangeticum and Glycyrrhiza glabra. It was observed that in previous studies of the Arab world, only ten species had been used as botanical pesticides, 34 species involved in food industry, 55 used in perfumery and cosmetology and 23 herbs are still in use of pharmaceuticals, out of 814 medicinal and traditional aids plant species [92].

The locally common, non-endemic and endangered species, Abrus precatorius (Joha) ground root powder [27] is taken orally along with cow's milk to treat scorpion stung victims [61].

The endangered species (Clitoria ternatea) is known locally as 'Gatad Marioti' [28, 29]. Its leaves and roots are usually used in the treatment of animal stings especially, scorpion stings and snakebites (flowers, stems and roots,) in India [62]. It is also used as an anthelmintic, in urogenital disorders, infections and general body aches [63]. Moreover, this plant has various pharmacological characteristics in functioning as a vascular smooth muscle relaxant, insecticidal, blood platelet aggregation inhibitor, antidiabetic, local anaesthetic, diuretic, anti-inflammatory, antimicrobial, antipyretic and analgesic [64].

habitat degradation and loss through overharvesting are some of the numerous factors that endanger the herbal plant diversity and its eradication altogether [93]. Symptomatic relief from the stress brought about by the scorpion stings could be attributed to the phytochemical contents of these herbal plants that act as analgesics, anti-pruritic and anti-inflammatory [94].

The herbal plant Desmodium gangeticum which, is locally known as 'Hiraija and Mabthora', is an endangered (and almost extinct), non-endemic species. This herbal plant has medicinal uses in India (ayurveda) [65, 66] for treatment of scorpion sting, snakebites, diabetes mellitus and ulcer $[67,68]$. The aerial parts of the herb extracts are identified as N,N-dimethyltryptamine, sterols and other derivatives, whilst, the root components are desmodin, gangetinin, gangetin and three more pterocarpinoids [69].

Glycyrrhiza glabra. This endangered non endemic, rare species belongs to the plant family Leguminosae (Fabaceae or Papilionaceae).

Its involvement in herbal medicine is represented in masking some medicinal preparations unpleasant tastes, scorpion stings, throat lozenges, cough mixtures, indigestion, inflammatory stomach conditions, stomach ulcers, and mouth ulcers [71].

It is observed that several plants mentioned in this recent study, contain various types of flavonoids, steroids, triterpenoids, alkaloids, tannins and coumarins. Full activity of a plant cannot be attributed to a single constituent; instead, full activity of a plant extract is due to the synergistic effect of various contents against various target structures (enzymes and receptors). Usually the chemistry of each of these contents has several and various functions and activities while they perform more than one biochemical or pharmacological function simultaneously. Studies of such plants would open a new era in the discovery of novel therapeutic agents, beneficial in scorpion envenoming, and secondly it would attract the attention of researchers to rationalize the use of these plants as a treatment for scorpion sting in traditional system of medicine. These rare and endangered plants which might have some potential ability to treat disease should attract special attention for conservation and prompt action in future research in the Kingdom.

\section{Conclusions}

In this review, the approach was investigated the phenomenon of rare and endangered medicinal plants, to open the door and emphasize the importance of their utilization in medical applications, safe effectiveness, source protection and longevity. It is quite evident that till now there are many unexplored plants that can be used to treat scorpion envenoming in general. Therefore, there is great demand for systematic surveys, deeper investigations and more appropriately thorough phytochemical application methods on these plants, before their extinction. Understanding of several other related pathological, physiological and pharmacological complications, are extremely essential within the field of envenoming and antidote process, especially in relation to scorpion sting syndrome.

\section{Abbreviations}

PDSA: Plant Diversity of Saudi Arabia; ACE: Angiotensin-Converting Enzyme; MSD: Medical Services Department; KSU: King Saud University 


\section{Acknowledgments}

The authors wish to thank the Medical Service Department, Ministry of Defense for their logistic help to conduct this study. Images were reproduced by kind permission from Dr. Jacob Thomas Pandalayil M.Sc., Ph.D., F.I.A.T. Asst. Professor/Curator, Herbarium King Saud University (KSU).

\section{Authors' contributions}

This work was carried out in collaboration between all authors. Authors AKAA designed the study; RA, NMAO, collecting literature and typed the manuscript. BAAA supervised and collected literature. The author(s) read and approved the final manuscript.

\section{Funding}

None.

\section{Availability of data and materials}

Not applicable.

\section{Ethics approval and consent to participate}

Not applicable.

\section{Consent for publication}

Not applicable.

\section{Competing interests}

The authors declare that they have no competing interests.

\section{Author details}

'Scientific Research Center, Medical Service Department (MSD), Ministry of Defense, P.O. Box 22454, Riyadh 11495, Kingdom of Saudi Arabia.

${ }^{2}$ Department of Dentistry, Ministry of Health, Riyadh, Saudi Arabia.

Received: 1 December 2019 Accepted: 7 July 2020

Published online: 29 July 2020

\section{References}

1. Uawonggul N, Chaveerach A, Thammasirirak S, Arkaravichien T, Chuachan C, Daduang S. Screening plants acting against Heterometrus laoticus scorpion venom activity on fibroblast cell lysis. Ethnol Pharm. 2005;103:201-7.

2. Bawaskar HS, Bawaskar PH. Scorpion sting: update. J Assoc Physicians India. 2012;60:46-55

3. Al-Asmari AK, Debboun M. Scorpions of Military Importance in Saudi Arabia: Morphological Characteristics, Clinical Profile and Management. Int Rev Armed Forces Med Serv. 2014:87(1):57-69.

4. Karnad DR. Management of scorpion envenoming: need for a standard treatment protocol using drugs and antivenom. J Assoc Physicians India. 2009;57:299-300.

5. Al-Asmari AK, Al-Saif AA, Hassen MA, Abdulmaksood NA. Role of prazosin on cardiovascular manifestations and pulmonary edema following severe scorpion stings in Saudi Arabia. Saudi Med J. 2009;29(2):1296-9.

6. Al-Asmari AK, Al-Zahrani AG, Al-Jowhary S, Arshadduddin M. Clinical aspects and frequency of scorpion stings in the Riyadh region of Saudi Arabia. Saudi Med J. 2012:33(8):852-8.

7. Goncalves E, Maia BT, Junior HM. Scorpion sting-induced unilateral pulmonary edema. Rev Soc Bras Med Trop. 2012;45(3):419.

8. Maheshwari M, Tanwar CP. Scorpion bite induced myocardial damage and pulmonary edema. Heart Views. 2012;13:16-8.

9. Dube S, Sharma VK, Dubey TN, Gouda NB, Shrivastava V. Fatal intracerebral haemorrhage following scorpion sting. J Indian Med Assoc. 2011:109:194-5.

10. Rubin DI, Vavra M. Brachial plexopathy as a rare presenting manifestation of scorpion envenoming. Muscle Nerve. 2011:44:131-5.

11. Naqvi R, Naqvi A, Akhtar F, Rizvi A. Acute renal failure developing after a scorpion sting. Br J Urol. 1998;82:295.

12. Natu VS, Kamerkar SB, Geeta K, et al. Efficacy of anti-scorpion venom serum over prazosin in the management of severe scorpion envenoming. J Postgrad Med. 2010;56:275-80.

13. Krishnan A, Sonawane RV, Karnad DR. Captopril in the treatment of cardiovascular manifestations of Indian red scorpion (Mesobuthus tamulus concanesis Pocock)envenoming. J Assoc Physicians India. 2007;55:22-6.
14. Deshpande SB, Pandey R, Tiwari AK. Pathophysiological approach to the management of scorpion envenoming. Indian J Physiol Pharmacol. 2008;52:311-4.

15. Sher $\mathrm{H}$, Al-Yemeni MN, Sher $\mathrm{H}$. Forest resource utilization assessment for economic development of rural community, northern parts of Pakistan. J Med Plants Res. 2010a;4(12):1197-208.

16. Rahman MA, Mosa JS, Al-Said MS, Al-Yahya MA. Medicinal plant diversity in the flora of Saudi Arabia 1: a report on seven plant families. Fitoterapia. 2004;75:149-61.

17. Khan S, Al-Qurainy F, Nadeem M. Biotechnological approaches for conservation and improvement of rare and endangered plants of Saudi Arabia. Saudi J Biol Sci. 2012;19:1-11.

18. Sher $\mathrm{H}, \mathrm{Al}-$ Yemeni MN, Yahya SM, Shah AH. Ethnomedicinal and ecological evaluation of Salvadora persica L: A threatened medicinal plant in Arabian peninsula. J Med Plants Res. 2010b:4(12):1209-15.

19. Katerere DR, Luseba D. Ethnoveterinary botanical medicine: herbal medicines for animal health. Cape Town: CRC Press, Taylor and Francis Group; 2010.

20. Shinwari ZK. Medicinal plants research in Pakistan. J Med Plants Res. 2010; 4(3):161-76.

21. Ghazanfar SA. Saline and alkaline vegetation of NE Africa and the Arabian Peninsula: An overview. In: Öztürk M, Waisel Y, Khan MJ, Görk G, editors. Biosaline Agriculture and Salinity Tolerance in Plants. Springer Verlag, Published by Birkhauser Basel 2007. p. 108-109. ISBN978-3-7643-7609-3.

22. Alagesaboopathi C. Ethnobotanical studies on useful plants of Kanjamalai Hills of Salem district of Tamil Nadu, Southern India. Arch Appl Sci Res. 2011;3(5):532-9.

23. Lalfakzuala $\mathrm{R}$, Lalramnghinglova $\mathrm{H}$, Kayang $\mathrm{H}$. Ethnobotanical usages of plants in western Mizoram. Ind J Trad Know. 2007:6(3):486-93.

24. Hammiche V, Maiza K. Traditional medicine in Central Sahara: pharmacopoeia of tassili N'aijer. J Ethnopharmacol. 2006;105(3):358-67.

25. Ghatapanadi SR, Johnson N, Rajasab AH. Documentation of folk knowledge on medicinal plants of Gulbarga district, Karnataka. Indian J Trad Know. 2011;10:349-53.

26. Abroug F, El-Atrous S, Nouira S, et al. Serotherapy in scorpion envenomation: A randomised controlled trial. Lancet. 1999;354:906-9.

27. Riuz-Teran F, Medrano-Martinez A, Navarro-Ocana A. Antioxidant and free radical scavenging activities of plant extracts used in traditional medicine in Mexico. African J Biotechnol. 2008;7:1886-93.

28. Singh V, Pandey RP. Ethnobotany of Rajasthan, India: scientific publishers, Jodhpur, Scientific Publishers; 1998. p. 367.

29. Singh A, Singh PK. An ethnobotanical study of medicinal plants in Chaudauli District of Uttar Pradesh. Ind J Ethnopharm. 2008;121:324-9.

30. Malla SB. Catalogue of Nepalese Vascular Plants. Minist. Forests Soil Conservation, HMG, Dept. Med. PI. Bull. 1976;7:1-211.

31. Ghazanfar, SA. Handbook of Arabian Medicinal Plants. Boca Raton: CRC Press; 1994. p. 265.

32. Girish KS, Mohanakumari HP, Nagaraju S. Hyaluronidase and protease activities from Indian snake venoms: neutralization by Mimosa pudica root extract. Fitoterapia. 2004:75:378-80.

33. Burkill HM. The useful plants of west tropical Africa. Kew: Royal Botanic Gardens; 1985.

34. Al-Farhan A, Al-Turki TA, Basahy RA. Flora of Jizan region, final report of project AR-17-7. King Abdulaziz City for Science and Technology (KACST). KSA. 2005;1:1-545

35. PDSA. Plant Diversity of Saudi Arabia. 2016 [Accessed 23 Nov 2016], http:// www.plantdiversityofsaudiarabia.info/

36. Burkill HM. The useful plants of west tropical Africa. Kew: Royal Botanic Gardens; 2004.

37. Ayyanar $M$, Ignacimuthu S. Herbal medicines for wound healing among tribal people in southern India: Ethnobotanical and scientific evidences. Int Appl Res Nat Prod. 2009;2:29-42.

38. Sandhya S, Vinod KR, Kumar S. Herbs used for brain disorders. Hygeia JD Med. 2010;2:38-45.

39. Pandikumar $\mathrm{P}$, Chellapandian M, Mutheeswaran S, Ignacimuthu S Consensus of local knowledge on medicinal plants among traditional healers in Myiladumparai block of Theni District, Tamil Nadu, India. J Ethnopharmacol. 2011;24:354-62

40. ljinu TP, Latha PG, George V, Pushpangadan P. Total phenolic and flavonoid contents and in vitro antioxidant potential of methanolic extract of Blepharis maderaspatensis (L.) B. Heyne ex Roth. Whole plant. Ann Phytomedicine. 2016;5(1):85-90. 
41. Collenette S. A checklist of botanical species in Saudi Arabia. - West Sussex; 1998.

42. Collenette S. Wild flowers of Saudi Arabia. Riyadh: National Commission for Wildlife Conservation and Development; 1999. https://catalog.hathitrust.org/ Record/004095049.

43. Chopra RN, Chopra IC, Handa KL, Kapur LD. Indigenous drugs of India. Calcutta: Academic Publishers; 1958

44. Yusuf M, Chowdhury JU, Wahab MA, Begum J. Medicinal plants of Bangladesh. Chittagong Bangladesh Council for Science and Industria Research (BCSIR); 1994

45. CRC World Dictionary of Medicinal and Poisonous Plants. 2012. [Accessed 1 Aug 2018]. http://www.agrifs.ir/sites/default/files/CRC\%20World\%2 0Dictionary\%20of\%20Medicinal\%20and\%20Poisonous\%20Plants, $\% 2$ 0Common\%20Names,\%20Scientific\%20Names,\%20Eponyms,\%2 OSynonyms,\%20and\%20Etymology,\%205\%20Volume\%20Set $\% 20 \%$ 7BUmberto\%20Quattrocchi\%7D\%20\%5B9781420080445\%5D\%20(2012).pdf.

46. Nandagoapalan V, Doss A, Marimuthu C. Ethnobotanical studies on usefu plants of pachamalai hills of Tiruchirappalli district of tamilnadu. J Adv Sci Res. 2016;7(1):14-9.

47. Gajalakshmi S, Divya R, Divya V, Deepika S, Sathiavelu MA. Pharmacologica activities of annona squamosa: a review. Int J Pharmaceutical Sci Rev Res. 2011;10(3):24-9.

48. Aké AL. Contribution aux études ethnobotaniques et floristiques au Togo, Collection "Médecine traditionnelle et pharmacopée", Agence de Coopération Culturelle et Technique; 1975. p. 153.

49. Aguilar-Guadarrama AB, Rios MY. Three new sesquiterpenes from croton arboreous. J Nat Prod. 2004;67:914-7.

50. Wang Y, Zou ZM. Sesquiterpenes from the stems of Croton caudatus Geisel. Var. tomentosus hook. Chin. J Nat Med. 2008;6:339-41.

51. McChesney JD, Clark AM, Silveira ER. Antimicrobial Diterpenes of croton sonderianus, 1. Hardwickic and 3,4- Secotrachylobanoic acids. J Nat Prod. 1991:54:1625-33.

52. Sutthivaiyakit $S$, Nareeboon P, Ruangrangsi N, Ruchirawat S, Pisutjaroenpong S, Mahidol C. Labdane and pimarane diterpenes from croton joufra. Phytochemistry. 2001;56:811-4.

53. Barbosa PR, Fascio M, Martins D, Silva Guedes ML, Roque F. Triterpenes of croton betulaster Euphorbiaceae. Biochem Syst Ecol. 2003;31:307-8.

54. Cai Y, Evans FJ, Roberts MF, Phillipson JD, Zenk MH, Gleba YY. Polyphenolic compounds from Croton lechleri. Phytochemistry. 1991;30:2033-40.

55. Aboagye FA, Sam GH, Massiot G, Lavaud JC. A glutarimide alkaloid from Croton membranaceus. Fitoterapia. 2000;71:461-2.

56. Attioua B. Contribution à l'étude phytocimique des feuilles et tiges de Croton lobatus (Euphorbiaceae), Ph.D., Dissertation, University of Strasbourg; 2005. p. 135.

57. Chabert P, Attioua B, Weniger B, Brouillard R. Croton lobatus, an African medicinal plant: spectroscopic and chemical elucidation of its many constituents. Bio Factors. 2006;27:69-78.

58. Manoharan S, Balaji R, Aruna A, Niraimathi V, Manikandan C, Babu MBV, Vijayan P. Preliminary phytochmical and cytotoxic property of leaves of Abrus precatorius Linn. J Herb Med Toxicol. 2010;4:21-4.

59. Vaidyarathnam PS, Varier S. Indian medicinal plants a compendium of 500 species. India: Orient Longman Pvt. Ltd.; 1995. p. 10-4.

60. Khare CP. Encyclopedia of Indian Medicinal Plants-Rational Western Therapy, Ayurvedic and other Traditional Usage. Germany, ISBN: 3-540-20033-9: Springer; 2004.

61. Bahekar S, Kale R, Nagpure S. A review on medicinal plants used in scorpion bite treatment in India. Mintage J Pharmaceutical Med Sci. 2012;1(1):1-6.

62. Kirtikar KR, Basu BD. Indian Medicinal Plants. Allahabad: Lalit Mohan Basu Publications; 1935. p. 802.

63. Patil AP, Patil VR. Clitoria ternatea Linn.: an overview. Int J Pharm Res. 2011;3:20-3.

64. Mukherjee PK, Kumar V, Kumar NS, Heinrich M. The Ayurvedic medicine Clitoria ternatea from traditional use to scientific assessment. J Ethnopharmacol. 2008;120:291-301.

65. Gosh D, Anandkumar A. Anti-inflammatory and analgesic activities of Gangetin-A pterocarpenoid from Desmodium gangeticum. Indian J Pharmacol. 1981;15:391-402.

66. Ghosal S, Bhattacharya SK. Desmodium alkaloids. II. Chemical and pharmacological evaluation ofDesmodium gangeticum. Planta Med. 1972;22: 434-40.

67. Dharmani P, Mishra PK, Maurya R, Chauhan VS, Palit G. Desmodium gangeticum: a potent anti-ulcer agent. Indian J Exp Biol. 2001;43(6):517-21.
68. Dharmani P, Palit G. Exploring Indian medicinal plants for antiulcer activity. Indian J Pharmacol. 2006;38:95-9.

69. Purushothaman K, Kishore VM, Narayanaswamy V. The structure and sterochemistry of Gangetin, a new pterocarpan from Desmodium gangeticum (Leguminosae). J Chem Soc. 1971;2420-2. https://doi.org/10.1039/J39710002420.

70. TCPermaculture, 2016. [Accessed 1 Aug 2018]. http://tcpermaculture.com/ site/2014/05/07/permaculture-plants-licorice-liquorice/.

71. Nadkarni AK. Indian materia medica. Bombay: Popular Prakashan; 1998.

72. Dinesh V, Bembrekar SK, Sharma PP. Herbal remedies used in the treatment of scorpion sting from the Nizamabad District, Andhra Pradesh, India. Sci Res Reporter. 2013;3(2):142-5.

73. Tilak JC, Adhikari S, Devasagayam TP. Antioxidant properties of Plumbago zeylanica, an Indian medicinal plant and its active ingredient, plumbagin. Redox Rep. 2004;9:219-27.

74. Thakur RS, Puri HS, Husain A. Major medicinal plants of India. Lucknow: Central Institute of Medicinal and Aromatic Plants; 1989.

75. Teshome K, Gebre-Mariam T, Asres K, Perry F, Engidawork E. Toxicity studies on dermal application of plant extract of Plumbago zeylanica used in Ethiopian traditional medicine. J Ethnopharmacol. 2008;117:236-48.

76. Chothani DL, Vaghasiya HU. A review on Balanites aegyptiaca Del (desert date): phytochemical constituents, traditional uses, and pharmacological activity. Pharmacogn Rev. 2011;5(9):55-62.

77. Bagul RM. Folk Ethnotherapies on scorpion sting among Tribals of east Khandesh region of Satpuda Forest, Maharashtra, India. Int J Sci Res. 2016; 5(10):1494-6.

78. Said O, Khalil K, Fulder S, Azaizeh H. Ethnopharmacological survey of medicinal herbs in Israel, the Golan Heights and the West Bank region. J Ethnopharmacol. 2002;83:251-65.

79. Abu-Irmaileh BE, Afifi FU. Treatment with medicinal plants in Jordan. Dirasat. 2000;27:53-74.

80. Abu-Irmaileh BE, Afifi FU. Herbal medicine in Jordan with special emphasis on commonly used herbs. J Ethnopharmacol. 2003:89:193-7.

81. Saad B, Dakwar S, Said O, Abu-Hijleh G, Al Battah F, Kmeel A, et al. Evaluation of medicinal plants hepatotoxicity in co-cultures of hepatocytes and monocytes. Evid Based Complement Alternat Med. 2006;3:93-8.

82. Lev E, Amar Z. Ethnopharmacological survey of traditional drugs sold in Israel at the end of the 20th century. J Ethnopharmacol. 2000;72:191-205.

83. Lev E, Amar Z. Ethnopharmacological survey of traditional drugs sold in the kingdom of Jordan. J Ethnopharmacol. 2002;82:131-45.

84. Azaizeh H, Fulder S, Khalil K, Said O. Ethnobotanical survey of local practitioners of the middle eastern region: the status of traditional Arabic medicine. Fitoterapia. 2003;74:98-108.

85. Cooper EL. Complementary and alternative medicine, when rigorous, can be science. Evid Based Complement Altern Med. 2004;1:1-4.

86. Muller WEG, Batel R, Schroder HC, Muller IM. Traditional and modern biomedical prospecting: part I — the history. Sustainable exploitation of biodiversity (sponges and invertebrates) in the Adriatic Sea at Rovinj (Croatia). Evid Based Complement Altern Med. 2004a;1:71-82.

87. Mueller WEG, Schroder HC, Wiens M, Perovic-Ottstadt S, Batel R, Muller IM Traditional and modern biomedical prospecting: part II-the benefits. Approaches for a sustainable exploitation of biodiversity (secondary metabolites and biomaterials from sponges). Evid Based Complement Altern Med. 2004b;1:133-44.

88. Ahmed MS, Honda G, Miki W. Herb drugs and herbalists in the Middle East. Tokyo: Studia culturae Islamicae, Institute for the Study of Languages and Cultures in Asia; 1979

89. Honda G, Miki W, Saito M. Herb drugs and herbalists in Syria and North Yemen. Tokyo: Studia culturae Islamicae, Institute for the Study of Languages and Cultures in Asia; 1990.

90. Eddouks M, Maghrani M, Lemhadri A, Ouahidi ML, Jouad $H$. Ethnopharmacological survey of medicinal plants used for the treatment of diabetes mellitus, hypertension and cardiac diseases in the south-east region of Morocco (Tafilalet). J Ethnopharmacol. 2002;82:97-103.

91. Heneidy SZ, Bidak LM. Potential uses of plant species of the coastal Mediterranean region, Egypt. Pak J Biol Sci. 2004;7:1010-23.

92. Azaizeh H, Saad B, Khalil K, Said O. The State of the Art of Traditional Arab Herbal Medicine in the Eastern Region of the Mediterranean: A Review. Evid Based Complement Alternat Med. 2006;3(2):229-35. https://doi.org/10.1093/ ecam/nel034 PMCID: PMC1475945.

93. Hamilton AC. Threats to plants: an analysis of centers of plant diversity. In: Touchell DH, Dixon KW, editors. Conservation into the 21 st century. Volume 
proceedings of 4th international botanic gardens conservation congress, Kings Park and Botanic Garden, Perth, Australia; 1997. p. 309-22.

94. Al-Asmari AK, Abbasmanthiri R, Abdo NM, Al-Duaiji FA, Khan HA. Saudi medicinal plants for the treatment of scorpion sting envenomation. Saudi J Biol Sci. 2017;24(6):1204-11. https://doi.org/10.1016/j.sjbs.2016.10.010 PMCID: PMC5562475.

\section{Publisher's Note}

Springer Nature remains neutral with regard to jurisdictional claims in published maps and institutional affiliations.

Submit your manuscript to a SpringerOpen ${ }^{\circ}$ journal and benefit from:

- Convenient online submission

- Rigorous peer review

- Open access: articles freely available online

- High visibility within the field

- Retaining the copyright to your article

Submit your next manuscript at $\boldsymbol{\sim}$ springeropen.com 